\title{
FLOODED RICE YIELD AS AFFECTED BY LEVELS OF WATER SALINITY IN DIFFERENT STAGES OF ITS CYCLE ${ }^{(1)}$
}

\author{
Thiago Isquierdo Fraga ${ }^{(2)}$, Felipe de Campos Carmona ${ }^{(3)}$, Ibanor Anghinoni ${ }^{(4)}$, \\ Silvio Aymone Genro Junior ${ }^{(5)}$ \& Elio Marcolin ${ }^{(5)}$
}

\begin{abstract}
SUMMARY
Losses of productivity of flooded rice in the State of Rio Grande do Sul, Brazil, may occur in the Coastal Plains and in the Southern region due to the use of saline water from coastal rivers, ponds and the Laguna dos Patos lagoon, and the sensibility of the plants are variable according to its stage of development. The purpose of this research was to evaluate the production of rice grains and its components, spikelet sterility and the phenological development of rice at different levels of salinity in different periods of its cycle. The experiment was conducted in a greenhouse, in pots filled with $11 \mathbf{d m}^{3}$ of an Albaqualf. The levels of salinity were 0.3 (control), $0.75,1.5,3.0$ and $4.5 \mathrm{dS} \mathrm{m}^{-1}$ kept in the water layer by adding a salt solution of sodium chloride, except for the control, in different periods of rice development: tillering initiation to panicle initiation; tillering initiation to full flowering; tillering initiation to physiological maturity; panicle initiation to full flowering; panicle initiation to physiological maturity and full flowering to physiological maturity. The number of panicles per pot, the number of spikelets per panicle, the 1,000-kernel weight, the spikelet sterility, the grain yield and phenology were evaluated. All characteristics were negatively affected, in a quadratic manner, with increased salinity in all periods of rice development. Among the yield components evaluated, the one most closely related to grain yields of rice was the spikelet sterility.
\end{abstract}

Index terms: yield components, spikelet sterility, Oryza sativa.

\footnotetext{
(1) Trabalho realizado em parceria entre o Instituto Rio Grandense do Arroz - IRGA e o Departamento de Solos da Universidade Federal do Rio Grande do Sul - UFRGS. Recebido para publicação em dezembro de 2008 e aprovado em novembro de 2009.

(2) Acadêmico do Curso de Agronomia, Universidade Federal do Rio Grande do Sul - UFRGS. Av. Bento Gonçalves 7712, CEP 91510-970 Porto Alegre (RS). Consultor de Mercado, Desenvolvimento e Inovação - Yara Brasil Fertilizantes. E-mail: isquierdofraga@yahoo.com.br

(3) Doutorando, Programa de Pós Graduação em Ciência do Solo, UFRGS. Bolsista CAPES. E-mail: felipecamposcarmona@hotmail.com

(4) Professor Adjunto, Programa de Pós Graduação em Ciência do Solo, UFRGS. Bolsista CNPq. E-mail: ibanghi@ufrgs.br

(5) Pesquisador do Instituto Rio Grandense do Arroz. E-mails: silvio-genro@irga.rs.gov.br; elio-marcolin@irga.rs.gov.br
} 


\title{
RESUMO: PRODUÇÃO DE GRÃOS DE ARROZ EM FUNÇÃO DE NÍVEIS DE SALINIDADE DA ÁGUA DE IRRIGAÇÃO EM DISTINTOS PERÍODOS DO SEU CICLO
}

\begin{abstract}
As perdas de produtividade das lavouras de arroz irrigado no Rio Grande do Sul podem ocorrer nas Planícies Costeiras e na região Sul devido à utilização de água salina de rios litorâneos, da Laguna dos Patos e de outras lagoas, sendo a sensibilidade da cultura variável conforme o seu estádio de desenvolvimento. O objetivo deste trabalho foi avaliar a produção de grãos de arroz e seus componentes, a esterilidade de espiguetas e o desenvolvimento fenológico da cultura em diferentes niveis de salinidade da lâmina de água em distintos períodos do seu ciclo. O experimento foi realizado em casa de vegetação, em vasos preenchidos com $11 \mathrm{~L}$ de um Planossolo Háplico. Os níveis de salinidade utilizados foram 0,3 (controle), 0,75, 1,5, 3,0 e

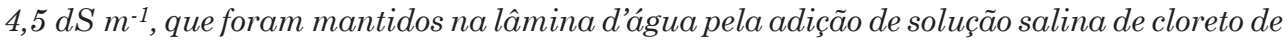
sódio, com exceção do controle, em diferentes períodos de desenvolvimento do arroz: V4 (perfilhamento) à diferenciação do primórdio floral; V4 ao florescimento pleno; V4 à maturação fisiológica; diferenciação do primórdio floral ao florescimento pleno; diferenciação do primórdio floral à maturação fisiológica e florescimento pleno à maturação fisiológica. Foram determinados o número de panículas por vaso, o número de grãos por panícula, o peso de mil grãos, a esterilidade de espiguetas e a produção de grãos, além do ciclo da cultura. Todos os atributos foram alterados negativamente, de forma quadrática, com o aumento da salinidade, em todos os períodos do desenvolvimento do arroz. Dos componentes de rendimento avaliados, o que mais se relacionou com o rendimento de grãos de arroz foi a esterilidade de espiguetas.
\end{abstract}

Termos de indexação: componentes de rendimento, esterilidade de espiguetas, Oryza sativa.

\section{INTRODUCTION}

The area under rice cultivation in Rio Grande do $\mathrm{Sul}$ is about one million hectares, concentrated in the Southern half of the State (IRGA, 2008). Virtually $100 \%$ of the fields are irrigated by flooding and the most used water sources are rivers, streams, ponds, lagoons and groundwater reservoirs. In the Southern region and Coastal Plains, the source most often used for irrigation comes from the Laguna dos Patos lagoon, whose area is $10,360 \mathrm{~km}^{2}$, the largest coastal lagoon in South America (Fernandes et al., 2005), with high potential for irrigation. Because of its linking with the Atlantic Ocean, the Laguna dos Patos lagoon suffers its influence, especially in times of low rainfall and high water demand, either from the atmosphere or own rice fields. November, December, January and February are the hottest months of the year and coincide with the rice fields irrigation time. During this period, with the decrease of the level of this lagoon, the entry of seawater occurs, resulting in an increase of salt concentration levels often harmful to the crop (Marcolin et al., 2005), which can potentially reach an area of about 200,000 ha of rice fields (Machado \& Terres, 1995).

The high levels of salts in irrigation water can restrict or even scupper the rice cultivation, also by the presence of some elements in toxic concentrations (Silva, 2004). As rice grows and increases its water demand, there is a tendency that a large amount of salt is deposited around the roots, by the increased evapotranspiration of plants (Grattan et al., 2002). Reductions in growth rate occur because, in addition to toxicity by high salt concentration, the plants become unable to absorb enough water, because of the decrease in the osmotic component of soil water potential (Tester \& Davenport, 2003). A prolonged stress causes wilting similar to that caused by drought, with a greenish-blue color, with thickened and greater waxied leaves (Ayers \& Westcot, 1985).

The tolerance of rice to salinity varies with its stage of development (Pearson, 1959). The stages of seedling and flowering are critical for the salinity of irrigation water. In salt levels above tolerable by rice plants, the water salinity causes a decrease in tillering and increases spikelet sterility (Ehrler, 1960). Several studies with different genotypes and different locations and environments (Fageria, 1991; Zeng et al., 2001; Grattan et al., 2002; Rodrigues et al., 2005; Melo et al., 2006) have shown a linear relationship between the increasing levels of salinity and the decrease in the number of tillers, in addition to increasing the number of non-productive tillers (Castillo et al., 2007). Salt stress also causes a reduction of photosynthesis, which occurs due to decreased availability of $\mathrm{CO}_{2}$ inside the leaf, by closing the stomata. This entails a series of cumulative effects, once water and osmotic potentials of leaves, stomatal conductance, transpiration rate, relative water content in the leaves, and synthesis of biochemical constituents are affected. These effects, combined, result in a shorter accumulation of photoassimilates in the leaves and affect the grain yield (Sultana et al., 1999). 
Electrical conductivity (EC) of irrigation water is the attribute most often used for monitoring the salinity of irrigation water, by the practicability of its measurement and high correlation with the amount of soluble salts, since the EC is the measure of resistance passage of electric current between electrodes in a solution where ionic solutes (cations and anions) are present (Doneen, 1975). Grattan et al. (2002) estimate a yield loss of $50 \%$ with an EC of around $7.4 \mathrm{dS} \mathrm{m}^{-1}$. In some cases, however, the salinity of soil solution from $1.9 \mathrm{dS} \mathrm{m}^{-1}$ is already sufficient to significantly reduce the seedlings biomass and an EC of $3.4 \mathrm{dS} \mathrm{m}^{-1}$ compromises their survival (Zeng \& Shannon, 2000).

As the salinity stress can occur throughout all the rice cycle, it's necessary to understand the plants behavior when exposed to salt stress at different stages of its development, as well as the effects on grain production. The objective of this study was to evaluate the grain yield of rice and its components, spikelet sterility and crop phenological development as affected by different salinity levels and in different stages from tillering.

\section{MATERIAL AND METHODS}

The experiment was conducted in pots in a greenhouse of the Soil Department of the Agronomy School at the Federal University of Rio Grande do Sul, Porto Alegre, Brazil, in the summer of 2006/07. An Albaqualf (Streck et al., 2008) soil was used, from the Laguna dos Patos Internal Coastal Plain, collected from the surface horizon $(0-20 \mathrm{~cm})$, air-dried and sieved in a $5 \mathrm{~mm}$ diameter mesh. The collected soil presented average values of $230 \mathrm{~g} \mathrm{dm}^{-3}$ of clay, $20 \mathrm{~g} \mathrm{dm}^{-3}$ of organic matter, $\mathrm{pH}$ in water $(1: 1)$ of 4.9 , $1.1,2.6$ and $1.1 \mathrm{cmol}_{\mathrm{c}} \mathrm{dm}^{-3}$ of exchangeable $\mathrm{Al}, \mathrm{Ca}$ and $\mathrm{Mg}\left(\mathrm{KCl} 1.0 \mathrm{~mol} \mathrm{~L}^{-1}\right)$, respectively, $118 \mathrm{mg} \mathrm{dm}^{-3}$ of available $\mathrm{K}$ (Mehlich-1), $40 \mathrm{mg} \mathrm{dm}^{-3}$ of available $\mathrm{P}$ (Mehlich-1), $4.4 \mathrm{cmol}_{\mathrm{c}} \mathrm{dm}^{-3}$ of exchangeable $\mathrm{Al}+\mathrm{H}$ (SMP) and $8.4 \mathrm{cmol}_{\mathrm{c}} \mathrm{dm}^{-3}$ of cation exchange capacity $\left(\mathrm{CEC}_{\mathrm{pH} \text { 7.0 }}\right.$ ) (Tedesco et al., 1995).

Eleven $\mathrm{dm}^{3}$ of dried soil were placed in pots of $13 \mathrm{~L}$ capacity, which was adjusted to a density of $1.2 \mathrm{~kg} \mathrm{dm}^{-3}$. Water was then added to achieve field capacity. The soil fertilization consisted of the application, prior to seeding, of $20 \mathrm{mg} \mathrm{dm}^{-3}$ of $\mathrm{N}, 15 \mathrm{mg} \mathrm{dm}^{-3}$ of $\mathrm{S}$, $120 \mathrm{mg} \mathrm{dm}^{-3}$ of $\mathrm{P}_{2} \mathrm{O}_{5}$ and $80 \mathrm{mg} \mathrm{dm}^{-3}$ of $\mathrm{K}_{2} \mathrm{O}$ per pot, in the form of ammonium sulfate, triple superphosphate and potassium chloride, respectively. After that, 20 seeds of rice cultivar IRGA 424 (short stature, medium cycle, long and fine grain and high tillering and productivity potential) were placed into the soil to germinate. When the plants reached the V4 stage (four fully expanded leaves), according to the Counce et al. (2000) scale, a top-fertilization of $100 \mathrm{mg} \mathrm{dm}^{-3}$ of $\mathrm{N}$ and $60 \mathrm{mg} \mathrm{dm}^{-3}$ of $\mathrm{K}_{2} \mathrm{O}$ per pot as urea and potassium chloride, respectively, was proceeded. The crop was irrigated from the V4 stage, by flooding, which occurred 15 days after seedling emergence, and maintained after thinning, six plants per pot.

Five levels of irrigation water salinity were used: 0.3 (control), $0.75,1.5,3.0$ and $4.5 \mathrm{dS} \mathrm{m}^{-1}$, kept in the water layer by the addition of sodium chloride saline solutions, except for the control, wich received only tap water. The adjustment of the water layer and salinity levels was done every two days, based on the electrical conductivity of each treatment. The minimum water layer depth never went below $5 \mathrm{~cm}$ and the maximum never exceeded $10 \mathrm{~cm}$. The salinity levels were applied at different stages of rice development, as follow: from tillering (V4) to panicle initiation (PI); from V4 to full flowering (FF); from V4 to physiological maturity (PM); from PI to FF; from PI to PM and from FF to PM. The full flowering phase was considered when at least $50 \%$ of viable stems of each plot reached the anthesis. The treatment with $0.75 \mathrm{dS} \mathrm{m}^{-1}$ salinity level, from PI, was discharged. Non saline water $\left(0.3 \mathrm{dS} \mathrm{m}^{-1}\right)$ was added to the pots before or after the treatments were applied. The water layer was maintained until the harvest of the experiment, which occurred when the grains moisture content reached approximately $22 \%$ of its total mass.

The pots were arranged according to a randomized block design, constituting a $6 \times 5$ factorial, for treatments that received saline water from V4, and $6 \times 4$ factorial, for those that received saline water from PI, with three replications. The control treatment initially had four replications, and one was used only to verify the panicle initiation of the main stem, and was then discharged, since most of the plants were destroyed. As soon as the control treatment reached the PI, the panicle differentiation was checked in one plant per pot for the other treatments, which was discharged, leaving five plants per pot. In this way, it was possible to determine the duration of the development stages of the plants, as well as the full cycle of plants at different levels of salinity.

All panicles of each pot were collected to determine the yield components (number of panicles per pot, number of viable grains per panicle and 1,000-kernel weight), spikelet sterility and grain yield per pot. The data represented the average of five plants per pot. After the number of panicles per pot was determined, plants were dried in an air forced ventilation oven at a temperature of about $50{ }^{\circ} \mathrm{C}$ until constant mass. The spikelets were separated from the rachis and primary and secondary panicle branches, selecting the viable spikelets to determine the number of grains per panicle, 1,000-kernel weight and grain production, adjusted to $13 \%$ of moisture. The mass determinations were carried out with precision electronic scale. The spikelet sterility was expressed as a percentage of the total number of spikelets per pot. The results were submitted to regression analysis, with the assistance of the graphical-statistical program SigmaPlot ${ }^{\circledR}$. 
Quadratic polynomial equations were used, which were the ones that best fit the data, presenting the statistical regression significance by the $\mathrm{F}$ test, together with the determination coefficient.

\section{RESULTS AND DISCUSSION}

The number of panicles per pot, number of grains per panicle and 1,000-kernel weight decreased and spikelet sterility increased with increasing salinity in the different evaluation periods from V4 (Figure 1). These effects were lower for the period of added salt from V4 to PI compared to the others, whose time under stress reached 49 days. These results, however, contradict those obtained by Zeng et al. (2001), where the greatest impact on grain yield of M-202, a short cycle rice cultivar, submitted to a period of salt stress of 20 days in solutions with $\mathrm{EC}$ of $4.6 \mathrm{dS} \mathrm{m}^{-1}$, occurred from V3 to PI. However, in this case, although the exposure period was significantly lower, it occurred before the tillering initiation, which begins from V4 (Counce et al., 2000), which may have caused a more intense decline in the number of tillers per plant, number of spikelets per panicle and grain weight per panicle. In the present study, these effects appear to have been reduced but not totally eliminated, as observed in grain production (Figure 1e), which was decreased by $50 \%$ compared to the control, from V4 to PI in the treatment with $\mathrm{EC}$ of $4.5 \mathrm{dS} \mathrm{m}^{-1}$. In the periods of V4 to FF and V4 to PM (Figure 1e), this reduction was achieved at lower salinity levels, 1.5 and $0.75 \mathrm{dS} \mathrm{m}^{-1}$, respectively. Considering an EC of $4.5 \mathrm{dS} \mathrm{m}^{-1}$, the yield losses was nearly total (97\%) in both periods.

Although the critical EC for irrigation water adopted for flooded rice in Rio Grande do Sul and Santa Catarina States, Brazil, is $2.0 \mathrm{dS} \mathrm{m}^{-1}$ (SOSBAI, 2005), in the present study, negative effects were found in an EC lower $\left(1.5 \mathrm{dS} \mathrm{m}^{-1}\right)$ than that previously stated, especially in the intervals of exposure to salinity between V4 and FF and V4 and PM. The 1,000-kernel weight (Figure 1c), spikelet sterility (Figure 1d) and grain yield (Figure 1e) were the most affected attributes. It should be noted, however, that even if the EC has been set at the water layer, all the added salt remained in the system. Considering that the study was carried out in pots, this must have generated a cumulative effect at the root zone. The results of Zeng \& Shannon (2000) support this hypothesis, since they grew rice plants in nutrient solutions with an EC of $1.9 \mathrm{dS} \mathrm{m}^{-1}$, very close to the critical level stated in Southern Brazil (SOSBAI, 2005), and observed a decrease in biomass production as early as 20 days after transplanting to pots in a greenhouse. On the other hand, from V4 to PI, the EC of $1.5 \mathrm{dS} \mathrm{m}^{-1}$ appears to have stimulated the number of grains per panicle (Figure 1b), and the grain yield (Figure 1e). Cui et al. (1995) also reported the positive effect of low
$\mathrm{NaCl}$ concentration $(0.1 \%)$ in nutrient solutions on the number and weight of grains of rice panicles.

In the case of water layer salinization from tillering, the yield components, as well as the spikelet sterility had a quadratic regression $(\mathrm{p}<0.05)$ with grain yield (Table 1). The 1,000-kernel weight was the least correlated $\left(R^{2}=0.82\right)$ feature with the water layer salinity and spikelet sterility the greatest correlated $\left(\mathrm{R}^{2}=0.96\right)$, which can be considered as the best attribute that explains the production of rice under salinity stress, while the number of grains per panicle $\left(R^{2}=0.85\right)$ and number of panicles per pot $\left(R^{2}=0.88\right)$ are at intermediate positions. The reduction in grain weight and increase in spikelet sterility were also the main causes for the reduction in grain yield in a field experiment in California (Grattan et al., 2002). However, in another experiment, these authors found that rather than the spikelet sterility, the reduction in rice yield was due to the reduction of panicles per unit area and grain weight, which demonstrates that different responses of rice yield components to salinity in different situations may occur.

As observed in the vegetative stage (Figure 1), during periods of salinization from PI (Figure 2) salinity affected all the evaluated attributes. Decreases of grain weight and grain yield, as well as a spikelet sterility increase, were similar for both periods of salt addition from PI to FF and from PI to PM (Figure 2c,e), which was also verified from V4 to $\mathrm{FF}$ and from V4 to PM (Figure 1c,e), indicating that the damage to rice by salinity can occur even when it begins at a later stage of plant development, such as at panicle initiation. However, there were major reductions in the number of panicles per pot from V4 to FF and from V4 to PM (Figure 1a) and in the number of grains per panicle from V4 to PM (Figure 1b), compared to those treatments in which the entry of salt water started later, in relation to PI (Figure 2a,b). It occurs because the number of panicles is defined not only after the PI, but before that stage of development. The number of grains per panicle might have been most affected in pots salinized from $\mathrm{V} 4$, due to the salinity in the root zone since the beginning of its development period, in relation to those which had started only in the PI, that delayed by a few days the process of soil salinization around the roots, causing minor damage to plant development.

The effects of salinity on the 1,000-kernel weight are contrasting in the literature. Just as it occurred in this study (Figures 1c and 2c), Zeng \& Shannon (2000) observed differences in this feature because of variations in salinity of the solution. In addition, they observed a compensatory effect by the decrease of the sterility and 1,000-kernel weight. When reducing the number of spikelets per panicle by salinity, a yield component formed earlier. In other words, when using the variety in that study (M-202), the ratio of spikelet fertility, and/or 1,000-kernel weight/number of spikelets tended to increase with increasing salinity 

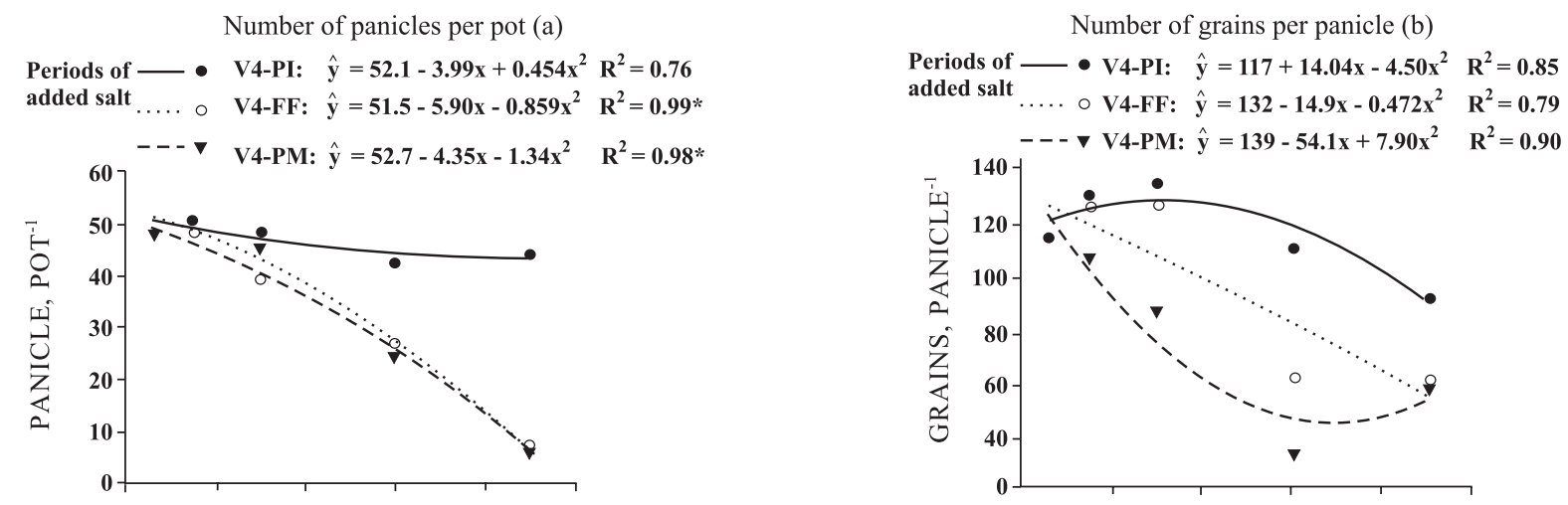

1,000 -kernel weight (c)
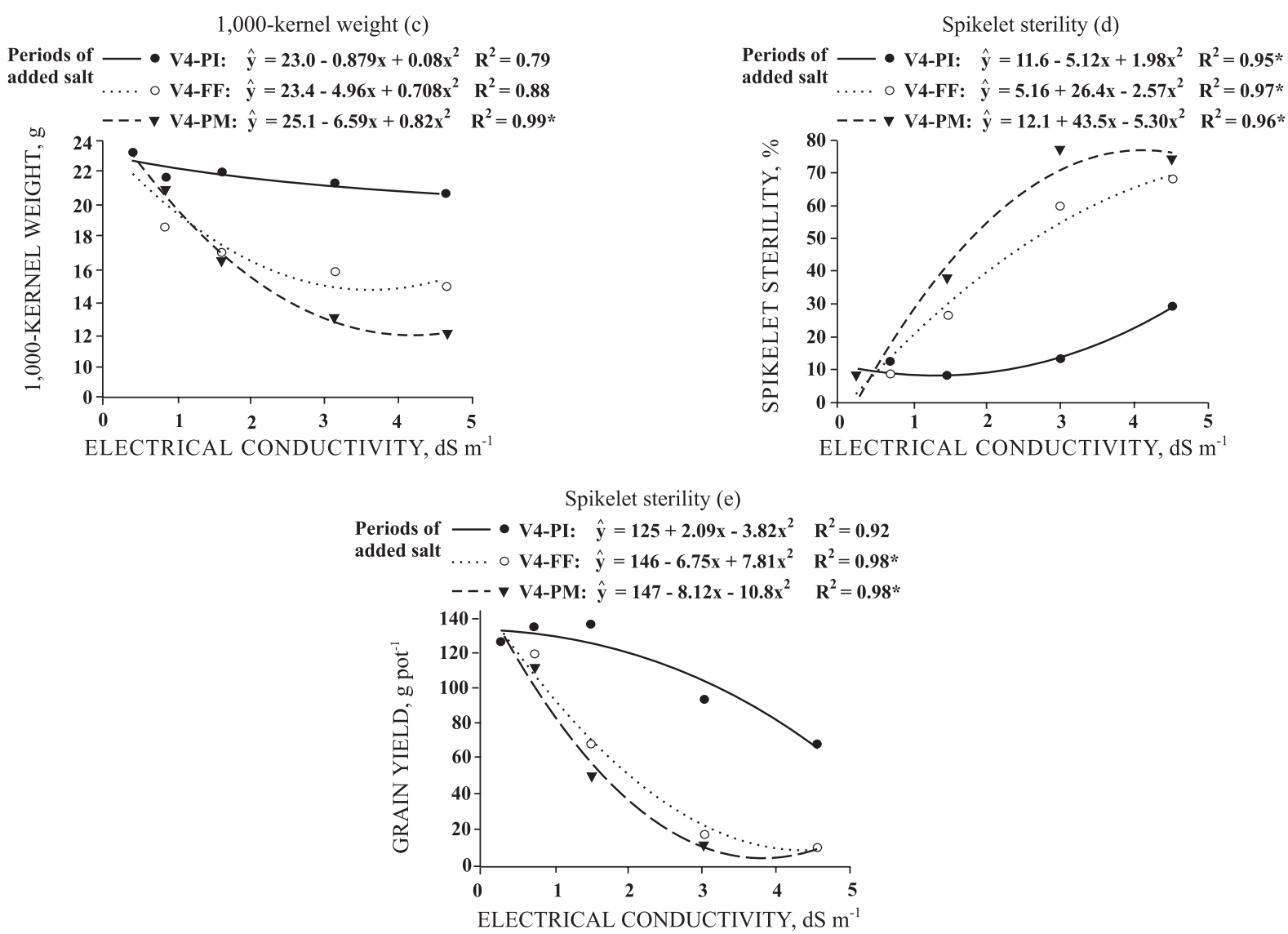

Figure 1. Number of panicles per pot (a), number of grains per panicle (b), 1-000 kernel weight (c), spikelet sterility (d) and grain yield (e) of flooded rice as affected by levels of salinity in different periods of its cycle, from tillering. *: Significant $(p<0.05)$.

conditions. However, testing the same variety, Grattan et al. (2002) did not observe changes in 1,000kernel weight in plants grown in pots in greenhouse conditions, unlike what happened in the field in a similar work, notwithstanding, in both cases, the EC of the water layer had reached $12 \mathrm{dS} \mathrm{m}^{-1}$.

Comparing the yield data, in the exposure to salinity from V4 to PI (vegetative stage) (Figure 1e) from PI to FF and from PI to PM (reproductive stage) (Figure 2e), it is noted that the effects were proportionately more severe in the reproductive period of cultivation, even though the time of exposure was lower. During the reproductive period of rice, salinity caused morphological changes similar to other environmental stresses that cause growth inhibition of plant structures, such as degeneration of primary and secondary rachis and of panicle spikelets (Cui et al., 1995).

The spikelet sterility was the best attribute related to grain yield of rice, both when the salinity was initiated at tillering $\left(\mathrm{R}^{2}=0.96\right)$, as from the reproductive period $\left(\mathrm{R}^{2}=0.98\right)$ (Table 1$)$. This was also observed by Kathun et al. (1995) comparing phases of rice development. Moreover, these authors found a 
Table 1. Relation between plant attributes and grain yield in different stages of flooded rice

\begin{tabular}{lcc}
\hline \multicolumn{1}{c}{ Rice attribute } & Regression equation & $\mathbf{R}^{\mathbf{2}}$ \\
\hline & Vegetative stage & $0.88^{*}$ \\
Number of panicles per pot $\left(\mathrm{x}_{1}\right)$ & Grain yield $(\hat{\mathrm{y}})=0.099 \mathrm{x}_{1}{ }^{2}-3.040 \mathrm{x}_{1}+18.496$ & $0.85^{*}$ \\
Number of grains per panicle $\left(\mathrm{x}_{2}\right)$ & Grain yield $(\hat{\mathrm{y}})=0.005 \mathrm{x}_{2}{ }^{2}+0.536 \mathrm{x}_{2}-36.893$ & $0.82^{*}$ \\
1,000 -kernel $\left(\mathrm{x}_{3}\right)$ weigth & Grain yield $(\hat{\mathrm{y}})=0.093 \mathrm{x}_{3}{ }^{2}+9.282 \mathrm{x}_{3}-136.330$ & $0.96^{*}$ \\
Spikelet sterility $\left(\mathrm{x}_{4}\right)$ & Grain yield $(\hat{\mathrm{y}})=0.024 \mathrm{x}_{4}{ }^{2}-3.724 \mathrm{x}_{4}+146.320$ & $0.59^{*}$ \\
& Reproductive stage & $0.91^{*}$ \\
Number of panicles per pot $\left(\mathrm{x}_{1}\right)$ & Grain yield $(\hat{\mathrm{y}})=0.158 \mathrm{x}_{1}{ }^{2}-7.548 \mathrm{x}_{1}+89.619$ & $0.93^{*}$ \\
Number of grains per panicle $\left(\mathrm{x}_{2}\right)$ & Grain yield $(\hat{\mathrm{y}})=-0.002 \mathrm{x}_{2}{ }^{2}+1.714 \mathrm{x}_{2}-75.629$ & $0.98^{*}$ \\
1,000-kernel $\left(\mathrm{x}_{3}\right)$ weigth & Grain yield $(\hat{\mathrm{y}})=0.241 \mathrm{x}_{3}{ }^{2}+2.599 \mathrm{x}_{3}-61.786$ & \\
Spikelet sterility $\left(\mathrm{x}_{4}\right)$ & Grain yield $(\hat{\mathrm{y}})=0.023 \mathrm{x}_{4}{ }^{2}-3.579 \mathrm{x}_{4}+144.920$ & \\
\hline
\end{tabular}

*: Significant $(\mathrm{p}<0.05)$.
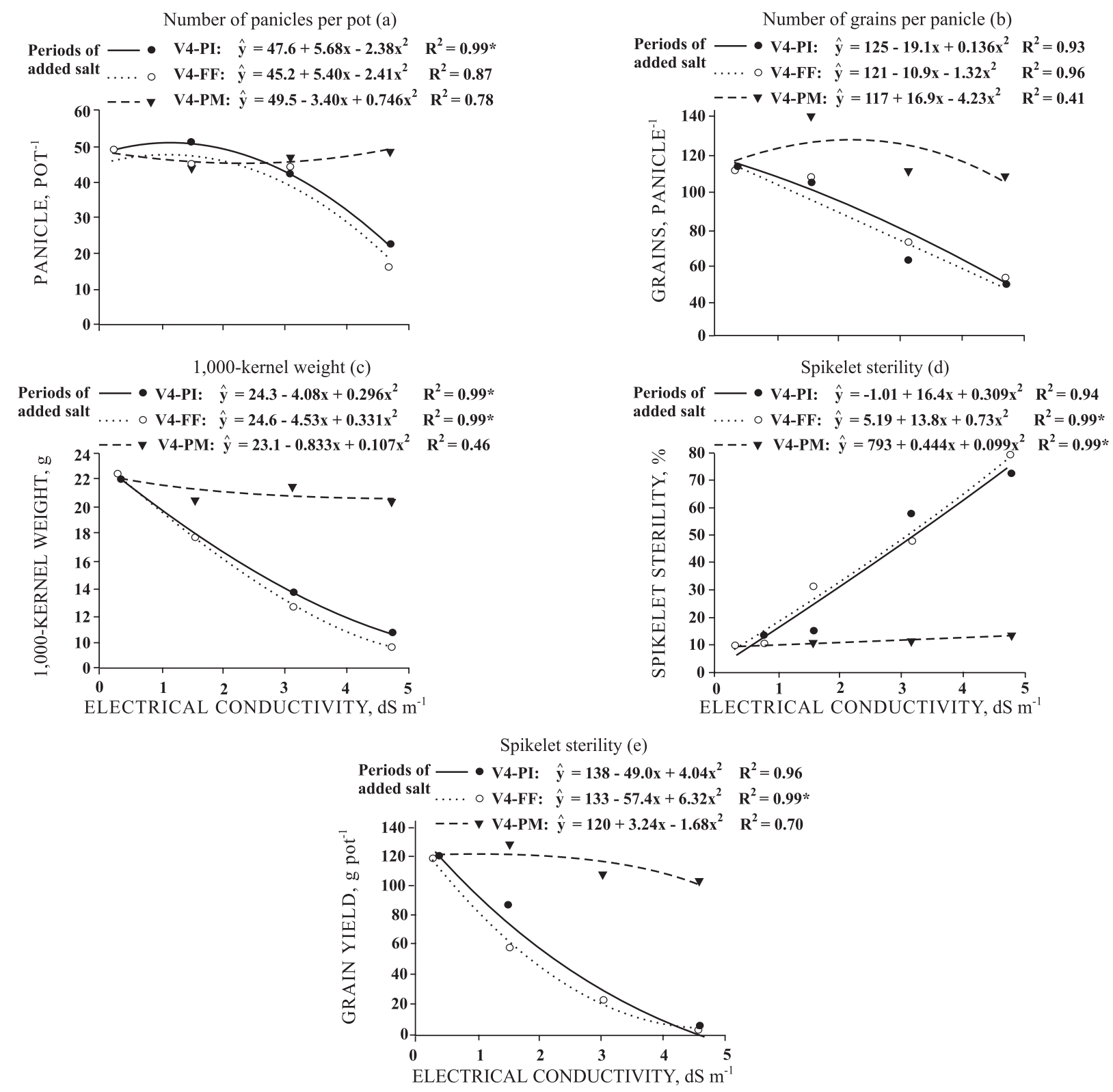

Figura 2. Number of panicles per pot (a), number of grains per panicle (b), 1-000 kernel weight (c), spikelet sterility (d) and grain yield (e) of flooded rice as affected by levels of salinity in different periods of its cycle, from panicle initiation. *: Significant $(p<0.05)$. 
correlation between sodium content of pollen and leaf flag, which can become a tool for the prediction of spikelet sterility. Since the differentiation of primary and secondary rachis and spikelet occurs during a brief interval in the early panicle formation, the salt stress prior to or during this phase causes further damage to the spikelets formation, compared to the stress caused after that period, which is very low or null (Zeng et al., 2001). This was also observed in the present work where, in the period between FF and PM (Figure 2a,e), the salinity had little effect on most evaluated attributes, demonstrating that the effect can be minimized if exposure occurs for short periods, or in stages in which the plant is less sensitive, as at grain milk (Sultana et al., 1999). The observed reduction in grain yield was only $15 \%$ in the level of $4.5 \mathrm{dS} \mathrm{m}^{-1}$ for the period from FF to PM (Figure 2e) compared to the control, but in other periods, this reduction was always greater than $95 \%$. Analysing the production functions, it can be observed that a grain yield reduction of $50 \%$ is achieved in salinity levels of $1.2,1.5$ and $2.0 \mathrm{dS} \mathrm{m}^{-1}$ for salt additions from V4 to PM (Figure 1e ), from PI to PM and from PI to FF (Figure 2e), respectively.

The response of yield components to salinity was different, comparing the imposition of stress after tillering (Figure 1) and from the reproductive period (Figure 2). From V4, the components that most affected the production of grains were, in order of importance, the number of panicles per pot, the number of grains per panicle and the 1,000-kernel weight. On the other hand, from the reproductive period, it was found that the number of panicles per pot was the characteristic that was less related to production. These results show the variability of responses to salinity in different periods and intensities. The yield components, according to Zeng \& Shannon (2000), have their own critical periods during the crop cycle, in relation to salinity regarding the effects on final grain production. For better understanding, it is necessary that the salinity stress is started and stopped, to enable the quantification of damage and the differences in sensitivity over the cycle, by comparisons of salinity levels with the same duration of stress in different stages of rice growing, as demonstrated by Zeng et al. (2001). This sensitivity should also be affected by climatic conditions in which the plant is grown, once different responses occur from the yield components under excess salts between seasons (wet and dry), yielding losses greater in conditions of low relative humidity (Asch et al., 1999). This can be attributed to increased plant transpiration and the consequent greater absorption and accumulation of salts in the rhizosphere (Asch et al., 1997). In the present study, the plant transpiration (data not shown) decreased from the salinity level of $1.5 \mathrm{dS} \mathrm{m}^{-1}$, from V4 to $\mathrm{FF}$, and the greater the level of salinity and exposure time, the lower the transpiration of plants. Thus, it is expected that differences also occur between trials in the field and in the greenhouse, since in the latter the highest average temperature can cause a decrease in the vegetative period.

A delay of up to 17 days in the reproductive period of rice for the highest levels of salinity in between the PI and FF (Table 2) was found. Likewise, Castillo et al. (2007), based on a study that evaluated the effect

Table 2. Duration of different development ${ }^{(1)}$ periods of irrigated rice as affected by the salinity of the water layer

\begin{tabular}{|c|c|c|c|c|}
\hline \multirow{2}{*}{$\begin{array}{c}\text { Electrical } \\
\text { conductivity (EC) }\end{array}$} & \multirow{2}{*}{ Periods of added salt } & \multicolumn{3}{|c|}{ Phenological stage } \\
\hline & & V4 to PI & PI to F F & FF to PM \\
\hline $\mathrm{dS} \mathrm{m}^{-1}$ & & 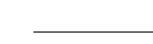 & _ days & 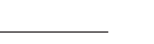 \\
\hline 0.3 & & $62 \mathrm{a}$ & $32 \mathrm{~d}$ & $18 \mathrm{a}$ \\
\hline 0.75 & $\begin{array}{l}\mathrm{V} 4-\mathrm{PI} \\
\mathrm{V} 4-\mathrm{FF} \\
\mathrm{V} 4-\mathrm{PM}\end{array}$ & $\begin{array}{l}62 \mathrm{a} \\
62 \mathrm{a} \\
62 \mathrm{a}\end{array}$ & $\begin{array}{l}32 \mathrm{~d} \\
32 \mathrm{~d} \\
32 \mathrm{~d}\end{array}$ & $\begin{array}{l}18 \mathrm{a} \\
18 \mathrm{a} \\
18 \mathrm{a}\end{array}$ \\
\hline 1.5 & $\begin{array}{l}\mathrm{V} 4-\mathrm{PI} \\
\mathrm{V} 4-\mathrm{FF} \\
\mathrm{V} 4-\mathrm{PM} \\
\mathrm{PI}-\mathrm{FF} \\
\mathrm{PI}-\mathrm{PM} \\
\mathrm{FF}-\mathrm{PM}\end{array}$ & $\begin{array}{l}62 \mathrm{a} \\
62 \mathrm{a} \\
62 \mathrm{a} \\
62 \mathrm{a} \\
62 \mathrm{a} \\
62 \mathrm{a}\end{array}$ & $\begin{array}{l}32 \mathrm{~d} \\
36 \mathrm{c} \\
36 \mathrm{c} \\
32 \mathrm{~d} \\
32 \mathrm{~d} \\
32 \mathrm{~d}\end{array}$ & $\begin{array}{l}18 \mathrm{a} \\
17 \mathrm{a} \\
17 \mathrm{a} \\
18 \mathrm{a} \\
18 \mathrm{a} \\
18 \mathrm{a}\end{array}$ \\
\hline 3.0 & $\begin{array}{l}\mathrm{V} 4-\mathrm{PI} \\
\mathrm{V} 4-\mathrm{FF} \\
\mathrm{V} 4-\mathrm{PM} \\
\mathrm{PI}-\mathrm{FF} \\
\mathrm{PI}-\mathrm{PM} \\
\mathrm{FF}-\mathrm{PM}\end{array}$ & $\begin{array}{l}62 \mathrm{a} \\
62 \mathrm{a} \\
62 \mathrm{a} \\
62 \mathrm{a} \\
62 \mathrm{a} \\
62 \mathrm{a}\end{array}$ & $\begin{array}{l}36 \mathrm{c} \\
43 \mathrm{~b} \\
43 \mathrm{~b} \\
36 \mathrm{c} \\
36 \mathrm{c} \\
32 \mathrm{~d}\end{array}$ & $\begin{array}{l}17 \mathrm{a} \\
17 \mathrm{a} \\
17 \mathrm{a} \\
17 \mathrm{a} \\
17 \mathrm{a} \\
18 \mathrm{a}\end{array}$ \\
\hline 4.5 & $\begin{array}{l}\text { V4 - PI } \\
\text { V4 - FF } \\
\text { V4 - PM } \\
\text { PI - FF } \\
\text { PI - PM } \\
\text { FF-PM }\end{array}$ & $\begin{array}{l}62 \mathrm{a} \\
62 \mathrm{a} \\
62 \mathrm{a} \\
62 \mathrm{a} \\
62 \mathrm{a} \\
62 \mathrm{a}\end{array}$ & $\begin{array}{l}43 \mathrm{~b} \\
-(2) \\
-(2) \\
49 \mathrm{a} \\
49 \mathrm{a} \\
32 \mathrm{~d}\end{array}$ & $\begin{array}{l}17 \mathrm{a} \\
-(2) \\
-(2) \\
-(2) \\
-(2) \\
17 \mathrm{a}\end{array}$ \\
\hline
\end{tabular}

(1) Defined by the scale of Counce et al. (2000) - V4: four fully expanded leaves; PI: panicle initiation; FF: full flowering; PM: physiological maturity. ${ }^{(2)}$ Not evaluated due to plant death. Means followed by the same letter in column do not differ by LSD test $(\mathrm{p}<0.05)$. 
of osmotic and ionic stresses on the rice variety IR64, observed that the higher the salinity level of the solution, the greater the delay of rice development, which reached 19 days. Whereas the range for sowing most of the cultivars used in the State of Rio Grande do Sul is 30 days. Delays of this magnitude, occurring in the field, will affect the yield components and spikelet sterility, not only because of salinity stress, but also due to lower solar radiation during the reproductive period.

\section{CONCLUSIONS}

1. The irrigation with saline water negatively affects the yield components, spikelet sterility and grain yield, and increases the rice cycle, with spikelet sterility being the most associated to yield.

2 . The entry of saline water from the panicle initiation affects grain yield, yield components and spikelet sterility in a similar way to the entry from the tillering stage.

3. The use of non-saline water from the panicle initiation to the physiological maturity reduces salinity damage on rice yield.

\section{LITERATURE CITED}

ASCH, F.; DINGKUHN, M. \& DÖRFFLING, K. Effects of transpiration on sodium and potassium distribution in salt-stressed irrigated rice. J. Exper. Bot., 48:39, 1997.

ASCH, F.; DINGKUHN, M.; WITTSTOCK, C. \& DOERFFLING, K. Sodium and potassium uptake of rice panicles as affected by salinity and season in relation to yield and yield components. Plant Soil, 207:133-145, 1999.

AYERS, R.S. \& WESTCOT, D.W. Water quality for agriculture. Rome, FAO, 1985. 184p. (FAO Irrigation and Drainage Paper, 29)

CASTILLO, E.G.; TUONG, T.P.; ISMAIL, A.M. \& INUBUSHI, K. Response to salinity in rice: Comparative effects of osmotic and ionic stresses. Plant Produc. Sci., 10:159-170, 2007.

COUNCE, P.A.; KEISLING, T.C. \& MITCHELL, A. A uniform, objective, and adaptive system for expressing rice development. Crop Sci., 40:436-443, 2000.

CUI, H.; TAKEOKA, Y. \& WADA, T. Effect of sodium chloride on the panicle and spikelet morphogenesis in rice. Japan. J. Crop Sci., 64:593-600, 1995.

DONEEN, L.D. Salinization of soil by salts in the irrigation water. Trans. Am. Geophys. Union, 35:943-950, 1975.

EHRLER, W. Some effects of salinity on rice. Bot. Gazette, 122:102-104, 1960.

FAGERIA, N.K. Tolerance of rice cultivars to salinity. Pesq. Agropec. Bras., 26:281-288, 1991.
FERNANDES, E.H.L.; CECÍLIO, R.O. \& SCHILLER, R.V. Estudo da influência da alteração dos molhes da barra de Rio Grande sobre a circulação do estuário da Lagoa dos Patos. Vetor, 15:49-57, 2005.

GRATTAN, S.R.; ZENG, L.; SHANNON, M.C. \& ROBERTS, S.R. Rice is more sensitive to salinity than previously thought. California Agric., 56:189-195, 2002.

IRGA. Disponível em: <http://www.irga.rs.gov.br/ ndex.php? action=dados_safra_lista\&categoria=1> Acesso em: 14 de jul. 2008.

KHATUN, S.; RIZZO, C.A. \& FLOWERS, T.J. Genotypic variation in the effect of salinity on fertility on rice. Plant Soil, 173:239-50, 1995

MACHADO, M.O. \& TERRES, A.L. Tolerância a genótipos à salinidade do solo - safra 1994/1995. In: REUNIÃO DA CULTURA DO ARROZ IRRIGADO, 21., Porto Alegre, 1995. Anais... Porto Alegre, IRGA, 1995. p.48-50.

MARCOLIN, E.; ANGHINONI, I.; MACEDO, V.M.; GENRO JUNIOR, S.A. \& VEZZANI, F.M. Salinidade da água na cultura do arroz no Rio Grande do Sul. Lav. Arroz., 53:27$38,2005$.

MELO, P.C.S.; ANUNCIAÇÃO FILHO, C.J.; OLIVEIRA, F.J.; BASTOS, G.Q.; TABOSA, J.N.; SANTOS, V.F. \& MELO, M.R.C.S. Seleção de genótipos de arroz tolerantes a salinidade na fase de germinação. Ci. Rural, 36:58-64, 2006.

PEARSON, G.A. Factors influencing salinity of submerged soils and growth of Caloro rice. Soil Sci., 87:198-206, 1959.

RODRIGUES, L.N.; FERNANDES, P.D.; GHEYI, H.R.; NERY, A.R. \& CORREIA, K.G. Produção de arroz em condições de salinidade a partir de mudas formadas com e sem estresse salino. R. Bras. Eng. Agric. Amb., 9:95-100, 2005.

SILVA, E.I.L. Quality of irrigation water in Sri Lanka - status and trends. Asian J. Water, Environ. Pollution, 1:5-12, 2004.

SOCIEDADE SUL-BRASILEIRA DE ARROZ IRRIGADO SOSBAI. Recomendações técnicas da pesquisa para o Sul do Brasil. Santa Maria, 2005. 159p.

STRECK, E.V.; KÄMPF, N. \& DALMOLIN, R.S.D. Solos do Rio Grande do Sul. 2.ed. Porto Alegre, Emater/RS/UFRGS, 2008. 222p.

SULTANA, N.; IKEDA, T. \& ITOH, R. Effect of NaCl salinity on photosynthesis and dry matter accumulation in developing rice grains. Environ. Exper. Bot., 42:211-220, 1999.

TEDESCO, J.M.; GIANELLO, C.; BISSANI, C.A.; BOHNEM, H. \& VOLKWEISS, S.J. Análise de solo, plantas e outros materiais. 2.ed. Porto Alegre, Universidade Federal do Rio Grande do Sul, 1995. 174p. (Boletim Técnico de Solos, 5)

TESTER, M. \& DAVENPORT, R. $\mathrm{Na}^{+}$tolerance and $\mathrm{Na}^{+}$ transport in higher plants. Ann. Bot., 91:503-527, 2003.

ZENG, L. \& SHANNON, M.C. Salinity effects on seedling growth and yield components of rice. Crop Sci., 40:996$1003,2000$.

ZENG, L.; SHANNON, M.C. \& LESCH, S.M. Timing of salinity stress affects rice growth and yield components. Agric. Water Manag., 48:191-206, 2001. 